\title{
The Paranoid Style in American History of Science *
}

\author{
George REISCH
}

Received: 31.5.2012

Final version: 30.7 .2012

BIBLID [0495-4548 (2012) 27: 75; pp. 323-342]

ABSTRACT: Historian Richard Hofstadter's observations about American cold-war politics are used to contextualize Thomas Kuhn's The Structure of Scientific Revolutions and argue that substantive claims about the nature of scientific knowledge and scientific change found in Structure were adopted from this cold-war political culture.

Keywords: Thomas S. Kuhn; The Structure of Scientific Revolutions; Richard Hofstadter; "The Paranoid Style in American Politics;" Cold War; James B. Conant; Brainwashing.

RESUMEN: Las observaciones del historiador Richard Hofstadter sobre la política americana en la Guerra Fría se utilizan para contextualizar La estructura de las revoluciones cientificas de Thomas Kuhn y sostener que algunas afirmaciones fundamentales sobre la naturaleza del conocimiento científico y el cambio científico que se pueden hallar en La estructura fueron adoptadas de esta cultura política de la Guerra Fría.

Palabras clave: Thomas S. Kuhn; La estructura de las revoluciones cientificas; Richard Hofstadter; "The Paranoid Style in American Politics"; Guerra Fría; James B. Conant; lavado de cerebro.

It is the use of paranoid modes of expression by more or less normal people that makes the phenomenon significant.

-Richard Hofstadter $(1964,4)$

\section{Introduction}

The conventional wisdom holds that Thomas Kuhn's Structure of Scientific Revolutions offered a revolutionary critique of existing scholarship about science. The book swept aside misconceptions wrought by three kinds of intellectuals-logic-chopping philosophers who confused their logical models and formulas with historical fact, Whiggish historians who viewed science's past through the lenses of the present, and text-book writers whose brief, potted historical introductions obscured science's dynamic, revolutionary history. As Kuhn announced in the famous first sentence of the book, history would liberate us from all these distortions:

History, if viewed as a repository for more than anecdote or chronology, could produce a decisive transformation in the image of science by which we are now possessed. (Kuhn 1962,1)

Since its publication in 1962, many intellectuals as well as professionals and the public have agreed. Structure remains today a starting point for anyone seeking a scholarly, sophisticated understanding of science and its history.

Yet it was surely not "history" alone-what Kuhn called "the historical record of the research activity itself'(1) — that corrected these misconceptions. Every historian

* I would like to thank Juan V. Mayoral and an anonymous referee for helpful comments and probing questions about an earlier draft of this essay. 
has a style according to which the unbounded, amorphous complexity of the past is reduced and transformed into plausible, ordered narratives or, in Structure, case studies. The historical past presented to us in Structure therefore speaks to us through Kuhn himself, through personal his biases and intellectual goals, as well as the many factors that make all intellectuals, even the most creative and independent, children of their time.

Kuhn's time, especially the years in which he first conceived and wrote Structure, from the late 1940s until its publication in 1962, was remarkable and extreme. The American public as well as many intellectuals were gripped by fears that communism was making inroads into American society and that democracy, Christianity, and other institutions could at any moment be eliminated by political revolution. Headlines described Russian spies and secret communists in government, education, and the media, while prominent anti-communists such as J. Edgar Hoover and Senator Joseph McCarthy warned repeatedly that America would be transformed were this foreign ideological invader not soon apprehended.

These and other excesses of McCarthyism and the cold war may seem remote and disconnected from the development of Kuhn's new historiography of science. Yet the origins of Structure as well as central elements of its style and content cannot be fully understood apart from these anti-communist anxieties and the underlying assumptions about human knowledge that made them seem plausible. The connections include Kuhn's relationship to Harvard President James B. Conant, who first sparked Kuhn's interest in history of science and from whom Kuhn learned to craft case studies. While Kuhn worked and taught side-by-side with him in Harvard's general education program, Conant was keenly interested in politics and diplomacy (and would soon become the United States Ambassador to West Germany, at a time when the divided city of Berlin was for many the epicenter of cold-war tensions between liberalism and communism). Conant was also a central figure in national debates and scandals involving the ideological loyalty of intellectuals (such as the physicist Robert Oppenheimer). Among other high-profile colleges and universities, Conant's Harvard was an important arena in which the nation struggled with the problem of communist faculty and the epistemological question at its core: was it was true (as anti-communist intellectuals like Sidney Hook, and eventually Conant himself, believed) that communist professors, most of whom had formulated their political views and beliefs during the ideologically tolerant 1930 s, were unfit to teach because their very abilities to think clearly and critically had been corrupted by their communism? ${ }^{1}$

While Kuhn studiously kept his professional scholarship separate from his political opinions and beliefs, his historiography of science nonetheless bears important marks of this complex national obsession with the fragility of liberalism and the widespread presumption that individuals, or an entire nation, could quickly and easily fall into communism's clutches and be irrevocably transformed. One trace of this preoccupa-

1 For more information on Conant's career, see Conant's autobiography (Conant 1970) and James Hershberg's biography (Hershberg 1993). Hershberg covers Conant's relationships to Oppenheimer and Sidney Hook in detail. On academic McCarthyism, see Schrecker (1986), and with specific reference to philosophy see McCumber (2001) and Reisch (2005). 
tion in Structure is a narrative style that was named by the historian Richard Hofstadter in his classic essay from 1964, "The Paranoid Style in American Politics" (Hofstadter 1964).

Here I will examine several elements of this style in order to show how Structure itself can be seen as a manifestation of it. One element is the axiom that fundamental change (in politics, in history of science) is revolutionary and total. This revolutionary axiom, in turn, supports a set of claims about the nature of political (or scientific) beliefs. One holds that they are holistic, non-decomposable, and incompatible with alternatives. It is impossible, for example, to be both a communist and a liberal democrat, just as one cannot be (for Kuhn) an adherent of two different paradigms (or parts of them). Another claim concerns the human mind and its relationship to ideas (political, for Hofstadter; scientific, for Kuhn). I call this claim "the brainwashing idea". It holds that ideas themselves can have special and sometimes total power over the human mind (and, consequently, human behavior).

\section{The Paranoid Style}

"The Paranoid Style in American Politics" appeared as an essay in Harper's Magazine in 1964, two years after Structure was published. To be sure, Hofstadter did not have Kuhn's new book or even current academic trends in mind when he published the essay. Hofstadter was, however, keenly interested in the status of ideas and intellectualism in America. His doctoral dissertation analyzed the career of social darwinism in America, and a year before "The Paranoid Style" appeared, he published his opus $A n$ ti-Intellectualism in American Life (Hofstadter 1963). In "The Paranoid Style", his goal was to contextualize the extreme political right, then epitomized by the histrionics of Senator Joseph McCarthy and his claim that "card-carrying communists" had secretly infiltrated Washington. The presidential campaign of that year also witnessed similar, conspiratorial claims about American government by the candidate Barry Goldwater and his supporters.

One of Hofstadter's goals was to reassure. Despite the press's tendency to sensationalize, his essay explained, these developments were not a new and ominous pathology in American life. Instead, they were symptomatic of a regularly recurrent 'style' of political thought in the United States. McCarthy's famous warnings about a communist "conspiracy on a scale so immense as to dwarf any previous such venture in the history of man", for example, were echoes of nineteenth-century warnings about scheming Jesuits and eighteenth-century claims about Masonry and its dangerous philosophy of Illuminism. "The paranoid style", Hofstadter explained, "is an old and recurrent phenomenon in our public life which has been frequently linked with movements of suspicious discontent" (Hofstadter 1964, 6).

Some features of Hofstadter's paranoid style will seem familiar to readers of Structure. One is the notion that change, when it comes, will be sudden and drastic, never incremental. As Hofstadter put it: 
The paranoid spokesman sees the fate of conspiracy in apocalyptic termsand death of whole worlds, whole political orders, whole systems of human values. He is always manning the barricades of civilization. He constantly lives at a turning point. (Hofstadter 1964, 29-30)

Another is Hofstadter's repeated use of the word "whole" to characterize what appears to be at stake for his paranoid politicians (namely, everything) and the related claim that change must be "apocalyptic" and total because these "whole political orders" and "whole systems of human values" are exclusive of alternatives:

Perhaps the central situation conducive to the diffusion of the paranoid tendency is a confrontation of opposed interests which are (or are felt to be) totally irreconcilable, and thus by nature not susceptible to the normal political processes of bargain and compromise. (Hofstadter 1964, 39)

For the nineteenth-century opponents of Masonry or cold-war anti-communists, the enemy did not threaten merely to alter or modify the familiar ways of life. The enemy threatened total revolution that would transform the status quo, eliminate all vestiges of the past, and effectively create a new world in which ideas and values, rights, property, and possibly lives would be unjustly lost.

Clearly some features of Hofstadter's paranoid style do not apply to Structure. Most scientists in its pages are "normal scientists" who are neither "suspicious" nor "discontent" with the scientific status quo. For them, scientific revolutions belong to the past, not the future, so they share none of the psychological and emotional paranoia that cold-war politicians routinely stoked to achieve their political ends. Nor are Kuhn's scientific revolutions the same as the political revolutions feared by Hofstadter's paranoids. Kuhn's science is professional science, a way of life unto itself that exists inside and largely independently of national and international politics.

Still, as the title of his book shows, Kuhn conceived the dynamics of scientific change by analogy with those of political revolution. ${ }^{2}$ Kuhn therefore had in mind a particular image of political revolution that matches what Hofstadter saw in the reasoning of his paranoids. Scientific change, for Kuhn, is revolutionary because his paradigms, like the "whole orders" Hofstadter described, are holistic, self-contained, and incompatible (or "incommensurable") with others. The rise of one requires that its predecessor become obsolete and, given the power of textbooks to rewrite scientific history (detailed in "The Invisibility of Revolutions"), largely forgotten by posterity. The comprehensive, monolithic qualities of paradigms, including the absence of any paradigm-independent observation language, led Kuhn to claim in Structure's longest chapter, "Revolutions as Changes of World View", that "when paradigms change, the world itself changes with them" (Kuhn 1962, 111). At least in this metaphorical sense, Kuhn joined Hofstadter's paranoids in conceiving of change in apocalyptic, worlddestroying and world-creating terms.

\footnotetext{
${ }^{2}$ Kuhn addresses and defends this analogy on the first pages of Chapter 9, "The Nature and Necessity of Scientific Revolutions" (92-94).
}

Theoria 75 (2012): 323-342 


\section{The Cold War and the Brainwashing Idea}

For Hofstadter, the brainwashing sensation of the 1950s was just another example of the paranoid's suspicious, exaggerated fears:

very often the enemy is held to possess some especially effective source of power: he controls the press; he has unlimited funds; he has a new secret for influencing the mind (brainwashing); he has a special technique for seduction (the Catholic confessional). $(1964,32)$

Readers would have been familiar with "brainwashing" because it was ubiquitous in American popular and political culture from onset of the Korean War in 1950. This war greatly advanced anti-communist anxiety in America because the invasion of South Korea by northern and Manchurian forces was widely seen as concrete evidence of Moscow's plans for world-domination. Americans were at the same time disturbed by reports about American soldiers who, after being captured by North Korean or Chinese armies, collaborated with their captors, murdered fellow soldiers, and subsequently refused repatriation to the United States when given the chance. Sparked by a series of articles written by Edward Hunter, a former CIA intelligence analyst turned news reporter, the brainwashing sensation offered a reassuring interpretation of these unpatriotic reports: the soldiers in question, Hunter explained, had been subject to "brainwashing", a new technique of psychological warfare developed by Moscow and now employed by partisans of international communism (such as China, whose communist revolution had taken place a year before). Through the machinations of their captors and no agency of their own, communist ideas had been placed in their minds. ${ }^{3}$ This foreign ideology then subverted and replaced the democratic ideas and values held by these soldiers. The very power of the ideas in question transformed them into fully-fledged, obedient communists, as if the brainwashing had induced a political, ideological revolution in each of these soldier's minds.

The underlying notion that ideas themselves can take control of an individual's mind and transform beliefs, values, and behavior, is well represented in Hofstadter's paranoid style. The "secrets" and "special techniques" taken to explain world history operate always in the service of larger systems of ideas or ideologies, such as communism, Illuminism, or Catholicism, that conquer and transform individuals. It is also central to the anticommunist politics that characterize the early cold war in America, focused as it usually was on individuals thought to have lapsed into communism and thus transformed into potential enemies of the state. In the late 1940s and early 50s, for example, the trials of State Department officer Alger Hiss, accused of communism by the former communist Whittaker Chambers, riveted the nation. Berkeley physicist J. Robert Oppenheimer, who was recruited by Conant to lead the Manhattan project, was accused of being a communist first in 1949 and then again (in a widely publicized hearing) in 1954. As a result, and despite Conant's efforts to defend his former chief physicist, ${ }^{4}$ the U.S. Atomic Energy Commission revoked Oppenheimer's security cre-

\footnotetext{
${ }^{3}$ See Hunter (1953). Illuminating recent accounts of the brainwashing sensation include Melley (2008) and Gleason (1995, esp. Chapter 5 "Brainwashing", 89-107).

${ }^{4}$ See Hershberg $(1993,318,678-79)$.
} 
dentials. Together with federal, state, and campus-level investigations into communist teachers, these sensational trials added credibility to the underlying brainwashing idea. The paranoid warnings from J. Edgar Hoover, Senator Joseph McCarthy and other anti-communists were perhaps not exaggerated or unreasonable: if ideas could really be so powerful, then anyone, regardless of professionalism, intelligence, or the degree of their patriotism (as the soldiers in Korea demonstrated) could fall into communism's ideological clutches and be transformed in a different kind of political person.

The brainwashing idea also saturated American popular and economic culture. It was foundational for the self-help industry founded in part by Norman Vincent Peale's The Powver of Positive Thinking, published in 1952. It convinced many that corporations and retailers routinely engaged in mind control through subliminal advertising, as Vance Packard explained in his 1957 best seller The Hidden Persuaders. Richard Condon's political thriller The Manchurian Candidate of 1959, about American soldiers brainwashed in Korea, gave brainwashing a cinematic visibility that it has enjoyed ever since.

\section{Brainwashing and Dogmatism}

The brainwashing idea also animates The Structure of Scientific Revolutions, beginning with the famous first sentence. Note that Kuhn does not say that we are mistaken for having embraced certain incorrect ideas about science. The agency, rather, belongs to our incorrect ideas, our false "image" of science. It has a hold on us, it 'possesses' us, Kuhn wrote, and will continue to control our thinking about science until that image is replaced by another that is completely different and incompatible — until, that is, our understanding of science itself undergoes something like a scientific revolution and change of paradigm.

The coincidence that Structure was published in 1962, the same year that John Frankenheimer's The Manchurian Candidate was released, would be merely suggestive were it not that Kuhn's depiction of professional scientists is similar to the film's victims of brainwashing. This is most prominent in Kuhn's essay "The Function of Dogma in Scientific Research" (Kuhn 1961) that he read in Oxford, England just prior to Structure's publication. He had recently finished a first, almost-complete draft of Structure and circulated it to Conant and others when he left for England to debut a paper that, he announced, "abstracted, in a drastically condensed form, from the first third of my forthcoming monograph The Structure of Scientific Revolutions" (Kuhn 1961, 347 , note 1).

Kuhn's focus was less the formal, historical structure of scientific revolutions than the temperament of professional scientists whose "dogmatic" cast of mind played an essential "function" in preparing for scientific revolutions. By emphasizing the word "dogma" and its variants, Kuhn's language in this essay was unmistakably saturated with political and ideological connotations. In particular, he emphasized, the popular image of scientists as open-minded, daring, and exploratory intellectuals (the kind that Conant celebrated in his historical writings about science) was usually false. Supposedly, the scientist "is the explorer of nature", Kuhn explained, 
the man who rejects prejudice at the threshold of his laboratory, who collects and examines the bare and objective facts, and whose allegiance is to such facts and them alone. . . To be scientific is, among other things, to be objective and open-minded. (Kuhn 1961, 347)

The truth is the opposite:

Though the scientific enterprise may be open-minded, the individual scientist is very often not. Whether his work is predominantly theoretical or experimental, he usually seems to know, before his research project is well under way, all but the most intimate details of the result which that project will achieve. If the result is quickly forthcoming, well and good. If not, he will struggle with his apparatus and with his equations until, if at all possible, they will yield results which conform to the sort of pattern which he has foreseen from the start. (Kuhn 1961, 348)

How does a community of scientists come to be so focused, confident, and dogmatic about the truth of their beliefs and the effectiveness of their methods? Through scientific education. Far from cultivating critical independence of mind, scientific education, Kuhn wrote, is "a relatively dogmatic initiation into a pre-established problemsolving tradition that the student is neither invited nor equipped to evaluate". ${ }^{5}$

The result of that education is paradigmatic indoctrination. Paradigms, Kuhn explained, are the "concrete problem-solutions" that science students learn through repetition and drills because "the profession has come to accept [them] as paradigms". Kuhn assumed that his audience was familiar with "paradigms" in "elementary language instruction or in training a musical instrumentalist" (Kuhn 1961, 351; see also 1959, 229). His new usage was similar, but paradigms were also bigger than exemplary problem-solutions. They are "scientific achievements" (Kuhn 1961, 352) that contain metaphysical and methodological beliefs that enable the paradigm's practices-they contain, that is, "a deep commitment to a particular way of viewing the world and of practising science in it" (Kuhn 1961, 349).

For three reasons, modern professional scientists working under a paradigm are dogmatic and fully committed to them. First, paradigms are exclusive. Any scientific community, he explained, "if it has a paradigm at all, can have only one" (Kuhn 1961, 352). Second, paradigms are taken to be true and unchanging representations of nature. As he had in Structure, Kuhn avoided using the word "truth" to make this point. ${ }^{6}$ Instead he described paradigms as "achievements" that are taken by scientists to be permanently recognized as such. Under an accepted paradigm, that is, scientists believe "the fundamental problems there resolved have, in fact, been solved once and for all" (Kuhn 1961, 353). Finally, scientists are contentedly dogmatic about their paradigms because they are the foundations of careers and livelihoods. A paradigm is "open-ended," with the result that scientists dedicate their careers to solving its puzzles. They "strive with all their might and will to bring it into closer and closer agreement with nature" (Kuhn 1961, 360).

Kuhn noted that the dogmatism of normal science was only one part of his new image of science, that this dogmatism eventually gives way as crisis and revolutionary

\footnotetext{
5 (Kuhn 1961, 351). Kuhn uses a nearly identical phrase in his $(1959,229)$. For a vivid, highly readable account of arguments over 'dogmatism' and 'indoctrination' then circulating in American debates over secondary school curricula, see Rudolph 2002. Though Rudolph does not emphasize it, Conant was a powerful, sometimes controversial, figure in these debates, as Hershberg's biography documents.

${ }^{6}$ See Kuhn 1962, 170-71.
} 
science render scientists more exploratory and critical about the foundations of competing paradigms. Still, as Kuhn's many liberal critics would point out, this critical, creative, and open-minded mode of science was exceptional and abnormal in Kuhn's account. ${ }^{7}$ Once a revolutionary successor paradigm has emerged, scientists either convert to the new paradigm or remain stubbornly in the old guard and end their careers along with the now obsolete paradigm. In all cases, scientific thinking and experimentation takes place within a guiding system of ideas, a paradigm, that is treated as an independent and powerful actor on the historical stage.

\section{A Manchurian Philosopby of Science?}

These parallels between the nature and function of communist ideology in brainwashing and paradigms in Kuhn's Structure-era philosophy of science are vividly illustrated by the famous opening dream-sequence of The Manchurian Candidate. As the film begins, Frank Sinatra's character Bennett Marco, a Korean War veteran, is asleep and experiencing a recurring nightmare. In the dream, he is seated on a stage alongside a dozen of his fellow soldiers from Korea. All of them are visibly bored by a middleaged matron who stands in front of them at a table as she lectures about cultivating hydrangeas. The camera pans slowly across the sleepy soldiers and then continuously around the room in a full circle. In the audience, a few dozen ladies eat cake, drink tea, and listen to the lecture. A sign next to the stage reads "Spring Lake Hotel, Mrs. Henry Whittaker, Hydrangeas, Fun, Hydrangeas".

Once the camera arrives back at its starting point, its literal revolution around the room reveals a revolution in perception and understanding. The plants and decorations that previously framed the podium are now poster-sized portraits of Mao, Stalin, and other communist heroes. Mrs. Henry Whittaker has become the diabolical military psychiatrist Dr. Yen Lo, sporting a fu Manchu mustache, and the audience is now an assortment of high-ranking communist military officials gathered in a modern auditorium for a demonstration of Dr. Lo's new psychological techniques. (See Figures 1 and 2.)

Due to their brainwashing, Dr. Lo explains, these American soldiers "believe that they are waiting out a storm in the lobby of a small hotel in New Jersey where a meeting of the ladies' garden club is in progress". As the doctor demonstrates the willingness of one soldier, the titular "candidate" who is being groomed as a political assassin, to kill anyone (even two of his fellow soldiers) on command, viewers are required to jump back and forth between these two incompatible gestalts. While the camera presents them sometimes in combination as if they are decomposable (Dr. Lo, for example, appears at one point in the hallucinatory hotel lobby [see Figure 3]), it is understood that the soldiers' understanding and perceptions are not decomposable. They are governed by and contained within the gestalt created by the brainwashing.

\footnotetext{
7 The majority of these critics were British. See Crombie (1961, 370-95) and Lakatos and Musgrave (1970). For an account of how Kuhn's paper was received at this conference, a reception that led him to drop the use of the word "dogma," see Reisch, forthcoming.
} 

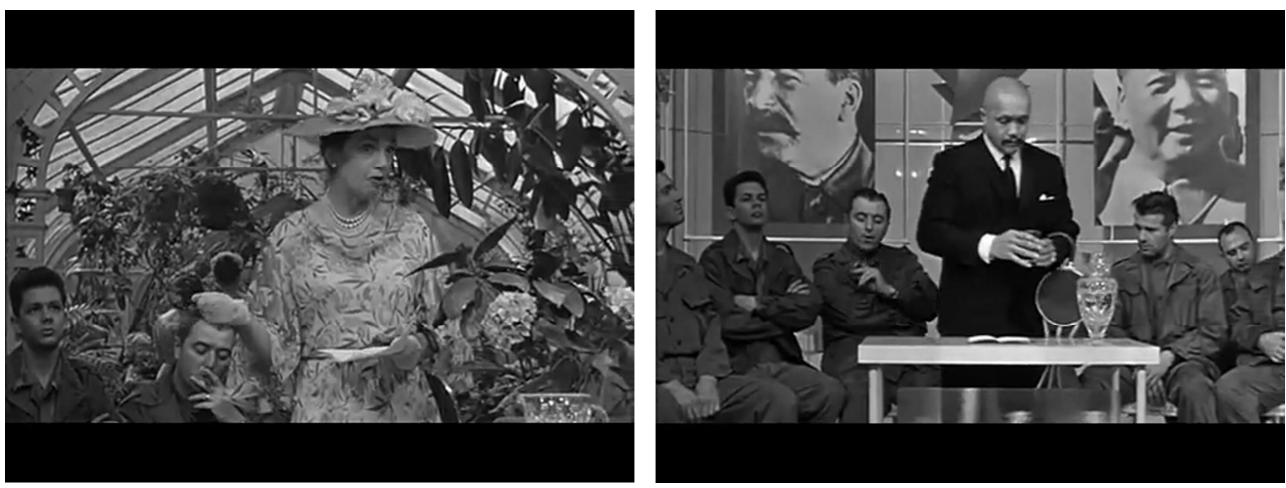

Figure 1: A meeting of a ladies' garden club (left) as experienced by the brainwashed soldiers on stage, is in fact a Communist military demonstration (right).
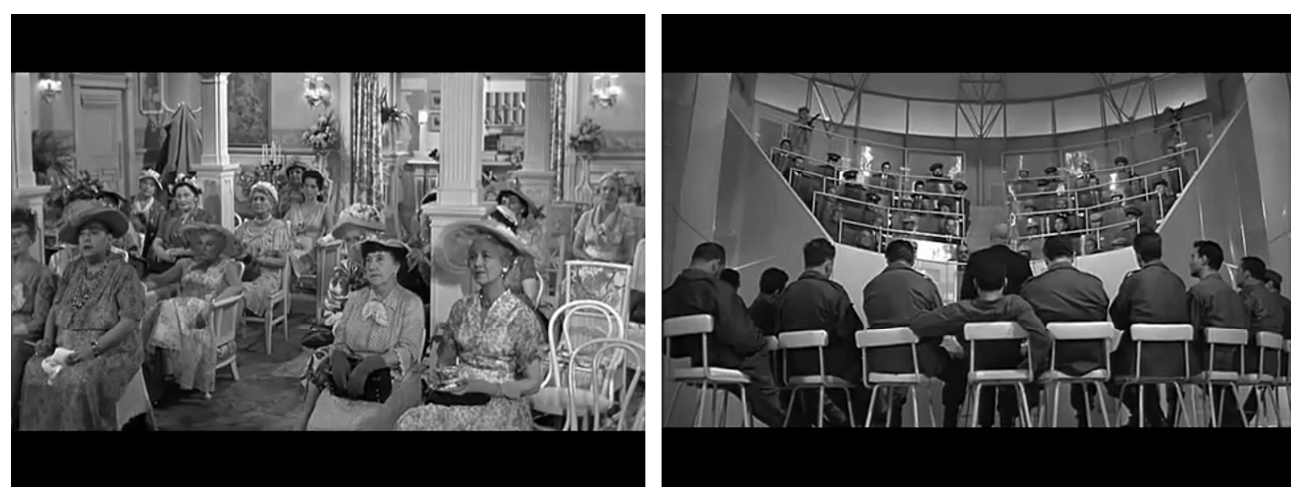

Figure 2: The audience attending to a lecture on bydrangeas (left) is in fact an audience of Communist military officers (right).
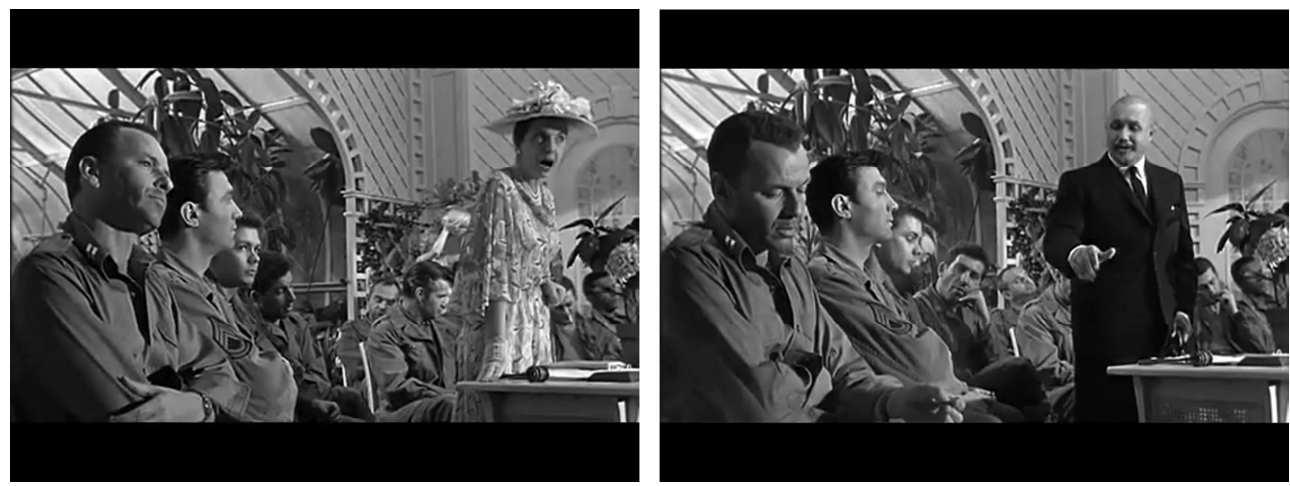

Figure 3: For the viewer, but not the brainwashed soldiers, the two gestalts are decomposable and presented sometimes in combination. 
The script's implicit account of brainwashing meets Kuhn's account of normal science and revolutions at five interrelated points.

(1) Conversion: The soldiers' brainwashing is transformative. It has turned them into effectively different people with different thoughts, perceptions, values, and (in the case of the assassin Raymond Shaw) moral sensibilities. Throughout Structure Kuhn similarly writes of scientists being "converted" to paradigms, and of paradigm shifts as "conversion experiences" that result in individuals understanding, and perceiving the world in dramatically different ways.

(2) Semantics: The brainwashing affects the meanings the soldiers recognize in various words. The speaker is not in fact uttering words and sentences about hydrangeas and their cultivation, but these soldiers believe this to be the topic of the presentation. Kuhn's paradigms similarly shape the meanings of scientific terms used and understood by scientists-this being one basis for Kuhn's celebrated claims that paradigms are "incommensurable" and that during revolutionary debates scientists may "talk through each other" (Kuhn 1962, 109).

(3) Theory-laden-observations: Even though the soldiers and Dr. Yen Lo's audience inhabit the same military auditorium in Manchuria, the soldiers perceive the room, its furnishings, and its occupants in qualitatively different, incompatible ways. Similarly, Kuhn explained, "when Aristotle and Galileo looked at swinging stones, the first saw constrained fall, the second a pendulum" (Kuhn 1962,121) because their different paradigms led them to see the same world differently.

(4) Individual variations: Though brainwashed presumably in the same ways, the soldiers do not share identical perceptions or interpretations of these events. Momentarily, the film reveals that in the eyes of one of the soldiers, an African American, Mrs. Henry Whittaker is African American. Few viewers would find this discrepancy puzzling. The brainwashing is understood to weave a new worldview and new experience from the memories, experiences, and expectations already present in the victims' minds. In Structure, individual differences among scientists play crucial roles during crises and revolutions. During pre-scientific activity and during revolutionary debates, when paradigms do not play their "normal" role in science, matters of "personal and historical accident" (Kuhn 1962, 4) shape scientific belief and behavior.

(5) Hidden Influence: Both Kuhn's scientists and Frankenheimer's soldiers are unaware that their thoughts and perceptions are guided by ideas that have been imposed upon them. Except for the dreams by which they are plagued, their shared memories of captivity and brainwashing have been erased. Understood as episodes in the self-brainwashing of scientific communities, Kuhn's revolutions become similarly 'invisible' to them after science textbooks are rewritten, as Kuhn explained in the chapter "The Invisibility of Revolutions" (Kuhn 1962, 136-43). 
The claim is not that Structure's account of science itself contains or involves brainwashing as depicted in this political thriller. Frankenheimer's soldiers were brainwashed against their will and by the force of their captors. Kuhn's conversions were initiated not by other people but by the dynamics of evidence and reason. As he wrote in Structure, "the transfer of allegiance from paradigm to paradigm is a conversion experience that cannot be forced" (Kuhn 1962, 151). The scope this "allegiance" is also reduced. While Hunter's captured GI's were thought to be totally transformed into a different kind of person (per communism's goal of populating the world with a kind of "new soviet man") ${ }^{8}$, Kuhn's scientific revolutions are professional revolutions that would appear to leave scientists' personalities and political inclinations intact and unaffected.

The same difference in scope is manifest when comparing Structure's claims about paradigms to claims about the transformative power of communist ideas by the era's most visible anti-communist crusader, FBI chief J. Edgar Hoover. His best-selling book Masters of Deceit, for example, described communism as a "world" and "way of life" unto itself:

The Communist Party, never forget, is a state within a state. It has its own system of 'courts,' legislative assemblies, schools, and press. It enforces its own laws, has its own standards of conduct, and offers its own road to Utopia. The Party member may physically reside in the United States, but he 'lives' in a communist 'world'. (Hoover 1958, vii)

Only abstractly and with great danger, Hoover insisted, can communism be understood as merely an "economic, political, social, or philosophical doctrine" or a harmless idea. It is instead an idea that becomes master to the slave who believes it:

It is a way of life; a false, materialistic 'religion.' It would strip man of his belief in God, his heritage of freedom, his trust in love, justice, and mercy. Under communism, all would become, as so many already have, twentieth-century slaves. (Hoover 1958, vi)

All Americans who had fallen under "the communist spell", Hoover wrote in its introduction, should "take the time to read this book-to see how, right before their eyes, the Party is deceiving them" and join other ex-communists who "once awakened to the true nature of communism, have renounced the Party" (Hoover 1958, vii, viii). In the language of Structure, Hoover hoped his exposé would be something like an 'anomaly' that would help lead those trapped within the communist 'paradigm' to a right-thinking 'paradigm shift'.

The comparison is possible only because Hoover, like Kuhn, helped himself to the reigning preoccupation with the brainwashing idea and the paranoid vocabulary of ideological transformation. Though he clearly did not intend that it be taken literally, Kuhn repeatedly wrote that revolutionary scientists stand at the door of 'new worlds' (Kuhn 1962, 111, 117, 118, 121, 135). In "The Function of Dogma”, Kuhn describes how paradigms govern the professional lives of normal scientists in terms that echo Hoover's claims about the controlling communist ideology. Kuhn wrote,

Their paradigm tells them about the sorts of entities with which the universe is populated and about the way the members of that population behave; in addition, it informs them of the ques-

8 As Hunter explained to the U.S. House of Representatives' Committee on Un-American Activities (Committee on Un-American Activities 1958). 
tions that may legitimately be asked about nature and of the techniques that can be used in the search for answers. In fact, a paradigm tells scientists so much that the questions it leaves for research seldom have great intrinsic interest to whose outside the profession. (Kuhn 1961, 359)

Comparing a professional scientist to a chess player, Kuhn's paradigms are much more than doctrines or ideas to be adopted or discarded as scientists find it useful to do so. Rather, paradigms enjoy a kind of transcendental priority that makes professional scientific life possible:

The paradigm he [the scientist] has acquired through prior training provides him with the rules of the game, describes the pieces with which it must be played, and indicates the nature of the required outcome. His task is to manipulate the pieces within the rules in such a way that the required outcome is produced. If he fails, as most scientists do in at least their first attacks upon any given problem, that failure speaks only to his lack of skill. It cannot call into question the rules which his paradigm has supplied, for without those rules there would have been no puzzle with which to wrestle in the first place. (Kuhn 1961, 362-63)

The entire, self-contained "way of life" that communism provided for Hoover's victims of Moscow was, for Kuhn, another explanation for why normal scientists tended to be 'dogmatic': When crisis and revolution loom, Kuhn explained, scientists tend to become increasingly dogmatic because they are defending, professionally speaking, everything they know and depend on- "neither more nor less than the basis of their professional way of life" (Kuhn 1961, 363).

\section{Kuhn's Aristotle Experience}

How did Kuhn's new conception of science come to align in these ways with popular images of brainwashing and mind-control? Much of the answer, though I do not have space to detail it here, lay in Kuhn's relationship to Conant.9 While there is abundant evidence that Kuhn's distinctive philosophical concerns were in place prior to his collaboration with Conant (Mayoral 2009; Isaac 2012), that collaboration set the stage for these developments in Kuhn's thought. Conant's conception of science and his historiography were themselves highly politicized by Conant's commitments to political and intellectual freedom, to the geopolitical value of scientific progress in the face of totalitarianism, and the historical advancement of learning (in the sense of Wissenscbaft, for the Germanophile Conant).

Kuhn was devoted to Conant and deeply impressed by his intelligence and acumen; but Kuhn did not aspire to be a public intellectual or defender of science and democracy. Yet by emerging from within the constellation of values and concerns that

${ }^{9}$ For an analysis of Kuhn's work that also leans heavily on Kuhn's relationship to Conant, see (Fuller 2000). The account given here of that relationship departs from Fuller's by focusing on Kuhn's rejection of certain features of Conant's conception of science and its history. While I agree broadly with Fuller's sense that Structure is an "exemplary document of the cold war era" (Fuller 2000, 5), the intellectual and political relationship between Kuhn and Conant in regard to the politics of the historiography of science is more complex and dynamic than Fuller admits. Kuhn did not, as Fuller writes, "simply [take] Conant's politics of science as uncontroversial-indeed, as a taken-for-granted worldview" (Fuller 2000, 6). More broadly the influences between Kuhn and Conant on these matters went both ways. As discussed below, Conant at first recoiled against Kuhn's theory of paradigms, but later came to accept some, but not all, of its claims and implications. 
Conant's historiography had embraced, Kuhn's new image of science was nonetheless shaped by these political and epistemological concerns. One issue on which Kuhn and Conant came to disagree, for example, was the nature of scientific progress. While Kuhn originally followed Conant in understanding scientific progress as a dialectical progression of "conceptual schemes" that variously confirmed, refuted, and inspired each other, ${ }^{10}$ a transformative event occurred in the summer of 1947, shortly into their collaboration. Conant had charged Kuhn with the task of reading original texts in ancient physics, and then it happened:

I was sitting at my desk with the text of Aristotle's Physics open in front of me... Looking up, I gazed abstractedly out the window of my room-the visual image is one I still retain. Suddenly the fragments in my head sorted themselves out in a new way, and fell into place together. My jaw dropped, for all at once Aristotle seemed a very good physicist indeed, but of a sort I'd never dreamed possible. (Kuhn 2000, 16; see also Kuhn 1977, xi-xii; Kuhn 1979, 1)

The experience led Kuhn to decide that the history of science is not a continuous accumulation of knowledge because scientists like Aristotle and Newton, the experience revealed, were not engaged in the same kinds of enterprises. They worked according to incompatible sets of intellectual values, goals, and metaphysical presuppositions, in something like "different worlds".

Structure must be understood, in part, as Kuhn's effort to understand the "revelation" of the Aristotle experience, to systematize its implications, and develop a new understanding of science on its basis. ${ }^{11}$ While one might conclude that this rejection of Conant's ideals of progress moved Kuhn away from Conant's politicized and liberal historiography of science, it rather moved Kuhn's developing image of science toward a different politics of knowledge. In place of Conant's ideal of Wissenschaft as an open, continuously expanding, and epistemologically transparent field of human learning, the Aristotle experience pointed to a fragmentation of this universal field, a fragmentation in which Hofstadter's paranoid style makes even more sense than it does in the context of Conant's anti-communist liberalism. In this fragmented universe, mutually exclusive and irreconcilable worldviews do battle for the winner-take-all supremacy familiar from the paranoid style.

The form in which Kuhn wrote about his Aristotle experience, in addition, seems to have drawn upon a prominent feature of this style: the conversion narrative. Besides the brainwashing sensation and its depiction in films like The Manchurian Candidate, the conversion narrative animated a thriving genre of mea culpa literature in the late 1940s and early 1950s. In books, magazines, and newspaper articles, former communists or fellow-travellers established their liberal bona fides by describing their former, usually youthful, experiences inside communism. Often, they described a sudden realization that communism's promises were false and its humanitarian ideals hollow. (See Reisch 2005, chapter 8.) Among the most popular was Whittaker Chambers' Witness (Chambers 1952), published four years after Chambers himself testified to the

${ }^{10}$ See, for example, Conant's attempt to define science in Conant (1947, 24-25). Kuhn knew this book well because he helped Conant proofread it prior to publication, as Kuhn mentions in his (2000, 275).

${ }^{11}$ Kuhn describes the centrality of the "terribly important" Aristotle experience in Kuhn (2000, 275, 292). He calls it a "revelation" in Kuhn $(1979,1)$. 
House Un-American Activities Committee that he had known State Department official Alger Hiss as a fellow comrade in the 1930s communist underground. Another bestseller during the cold war was the novel Darkness at Noon by Arthur Koestler who, among other things, was like Kuhn a physicist turned historian of science. While Koestler's famous novel details the political disillusionment of a fictional, imprisoned Bolshevik whose party had turned on him, Koester's personal, autobiographical description of his youthful conversion to communism reads strikingly like Kuhn's conversion to Aristotelianism. ${ }^{12}$

Koestler describes his conversion in The God that Failed: A Confession, a collection of conversion narratives by former communist intellectuals published in England in 1950. As it was for Kuhn, the event occurred when Koestler was reading:

Tired of electrons and wave mechanics, I began for the first time to read Marx, Engels, and Lenin in earnest. By the time I had finished with [Marx's Theses on] Feuerbach and [Lenin's] State and Revolution, something had clicked in my brain which shook me like a mental explosion. To say that one had 'seen the light' is a poor description of the mental rapture which only the convert knows (regardless of the faith he has been converted to). The new light seems to pour from all directions across the skull; the whole universe falls into a pattern like the stray pieces of a jigsaw puzzle assembled by magic at one stroke. (Koestler 1950, 23)

Kuhn did not become a dogmatic Aristotelian in the same way that Koestler became, for many years, a convinced, dogmatic Marxist. But the revolutionary scientists Kuhn would write about in Structure do experience sudden, unanticipated conversions that they too describe in similar language: "Scientists then often speak of the 'scales falling from the eyes' or of the 'lighting flash' that 'inundates' a previously obscure puzzle" (Kuhn 1962, 122).

The Aristotle experience suggests how these cold-war themes and tropes came to leave their mark on Structure. For Kuhn's experience was highly subjective, personal, and shocking to him precisely because nothing in his education had prepared him for it. It presented him, that is, with a range of questions that he set out to answer on his own. Was the experience truly revealing and important, or was it more like a hallucinatory daydream on a very hot summer afternoon? If it was genuinely revealing of scientific understanding, did it point to Kuhn's own particular ways of understanding science, or to general, objective features of understanding? Judging from Kuhn's descriptions of the experience and from his surviving notes and papers, he read far and wide in sociology, psychology, and philosophy, searching for illuminating tools and perspectives. These explorations led him to Piaget, Fleck, and later, in the late 50s, to Wittgenstein and Bruner's psychology experiments (Cedarbaum 1983; Isaac 2012).

Neither individually or collectively, however, would these sources have been likely to lead Kuhn to the distinctive revolutionary picture of science articulated in Structure. This is not to deny that these sources played various roles. Ludwig Fleck's theory of "thought collectives" in science, for instance, are quite similar to Kuhn's normalscientific communities and Kuhn acknowledged the considerable influence of Fleck's Genesis and Development of a Scientific Fact when he encountered it during his "explorato-

12 As a historian of science, Koestler's main work is The Sleepwalkers (Koestler 1959), a study of Kepler's work that grew into a larger analysis of the Copernican revolution. 
ry" reading at the time (Kuhn 1979, viii-ix; see also Cedarbaum 1983, 199-200). Like the brainwashed soldiers in The Manchurian Candidate, Fleck's professional scientists live and work under a shared "harmony of illusions" that is maintained by the "thought-style" of the collective. Yet Fleck's text says very little about scientific revolutions and never identifies them transitions from one thought-style to another. To the contrary, Fleck speaks of scientific facts and ideas being in constant and "continuous" evolution (Fleck 1979, 95). The likely influences of Polanyi, Piaget, and Wittgenstein, all of whom Kuhn refers to in Structure, also bear on the original acquisition of concepts by the individual and, with Polanyi, the "tacit" (Polanyi 1958), inarticulated status of scientific concepts understood by professional scientists. While relevant to the understanding of scientific revolutions as Kuhn describes them, none of these sources seems likely to have inspired the notion of revolution-as-conversion that Kuhn presents in Structure. ${ }^{13}$

Sources of Structure that do address sudden, transformative change are psychological, including the gestalt and new-look psychology manifest in Kuhn's discussions of ambiguous figures (such as the duck-rabbit) and the perceptual experiments of Stratton and Bruner and Postman. But by themselves these concern matters of perception and seeing, not matters of scientific practice and theoretical understanding. One of Kuhn's central innovations in the wake of the Aristotle experience was to assimilate sudden perceptual change with revolutionary change in scientific understanding; to claim, in effect, that revolutionary scientific change in history is just like the shift in understanding he personally experienced on that hot summer day in 1947: it is sudden, total, and connected to different gestalts or worldviews that are irreconcilable. For that assimilation to seem plausible, however, it requires some account of how a sufficient number of individuals in a community can come to experience, more or less simultaneously, a transformative conversion experience. The brainwashing idea, circulating at the time in North America, provided that plausibility.

Like everyone else in North America, Kuhn was surrounded by the brainwashing idea and the paranoid sensibility. He would not have had to learn about them by visiting Widener Library. Nor is it necessary to explain why Kuhn might have taken these ideas seriously, as if they belonged only to sensational headlines. For these ideas were then taken seriously by very intelligent people. During the years of their collaboration, for example, Conant engaged the brainwashing idea in the controversy over com-

${ }^{13}$ For an account of Kuhn's appeal to Wittgenstein as support for, but not inspiration of, his theory of paradigms, see Isaac (2012). On Kuhn's debt to Polanyi and continuing debate about the extent of it, see Jacobs $(2006 / 2007 ; 2009)$. On Kuhn's debt to Piaget, Kuhn himself explains how Piaget helped him interpret his Aristotle experience (see Kuhn 1971, 21). Yet Kuhn's remarks about Piaget's theory of developmental stages suggest again that only after Kuhn had formulated his notion of scientific revolution, as a simultaneous shift in conceptual apparatus and experience of the world, did he appeal to Piaget's theories of learning as support. On their own, Piaget's studies fell short of suggesting Kuhn's notion of revolution-as-conversion because they addressed concept formation and not changes in the very experience of nature that Kuhn attached to revolutions. Only when "nature and conceptual apparatus are jointly implicated in the contradiction posed by thought experiments" (Kuhn 1964, 265), that is, did Kuhn cite Piaget's children as a helpful but incomplete introduction to scientific revolutions in their historical fullness. 
munist teachers. Though he originally defended the civil and intellectual rights of communist faculty against anti-communists seeking to purge education of communist influence, events of 1948, Conant's biographer explains, including the Berlin Airlift and growing anti-communist hysteria in the popular press (Look magazine asked on its cover of August 3, "Could Reds Seize Detroit?") led Conant to revise his views. He came to accept the consensus among university administrators that "party members were beyond the pale as teachers" (Hershberg 1993, 423, 424, 450). A statement from the National Education Association, in which Conant was an influential member "primus inter pares," offered a popular rationale: "The whole spirit of free American education will be subverted unless teachers are free to think for themselves" (Hershberg 1993, 430, 453). The brainwashing idea is unmistakeable in the NEA's opinion: communist intellectuals are not "free to think" precisely and only because communist ideology has taken control of their intellectual faculties.

Conant's own fear of a final, nuclear war between the United States and the Soviets peaked arguably in February 1950. That is when he learned that President Truman had decided to pursue the development of the H-bomb, against objections from himself, George F. Kennan, and others that the super-bomb would unwisely escalate geopolitical tensions. Days later, Conant heard the news that Klaus Fuchs, a native German physicist whom Conant knew from the Manhattan project, had been revealed as a Soviet spy. "That man knew everything, that man knew everything!" Conant muttered, ashen faced, when he heard the news. Twelve days after that, with Senator Joseph McCarthy now "ranting and raving on the Senate floor from afternoon until past midnight about alleged State Department communists", Conant wrote from Washington to Robert Oppenheimer that the city "seems as though I am in a lunatic asylum, but I am never sure who is the attendant and who the inmate". 14

While there appears no evidence of conversations between Kuhn and Conant specifically about these unstable and potentially catastrophic political conditions, it is plain that these elements of the paranoid style were part of the texture and climate in which Kuhn first learned how to research and teach history of science. They did not eclipse the better-known sources on which Kuhn drew as he developed Structure, but they existed alongside these sources in the repertoire of concepts, background assumptions, sensibilities, and literary tropes that any historian brings to the task of interpreting and making sense of the past.

\section{Conclusion: James Conant Reads The Structure of Scientific Revolutions}

When Conant first read an early draft of Structure in the spring of 1961, he was faced with a conceptual rebellion, if not a revolution, in the form of Kuhn's new theory of paradigms. Conant's notion of historical progress as the sciences move from once conceptual scheme to another was obviously in jeopardy if it were true that every scientific revolutions brought with it a new "world view". In a long, detailed letter, Co-

\footnotetext{
${ }^{14}$ McCarthy's antics were so described by journalist Richard Rovere in a letter to Conant. For this, Conant's letter to Oppenheimer, and Conant's reaction to news about Fuchs, see Hershberg 1993, 483.
} 
nant explained that while he liked the book's general approach, this new theory of paradigms had led Kuhn to pay too much attention to theories and world views and too little to the history of experimentation, instruments, and the "practical arts", all of which were essential to Conant's conception of scientific advancement and progress. This neglect created "needless trouble about [scientific] progress" in the manuscript, Conant wrote, and it would create trouble for Kuhn if readers agreed that the author used "paradigm" as "a magic verbal word to explain everything!" 15

In his reply to Conant, the Aristotle experience sits recognizably between the lines. Kuhn wrote,

This is the most fundamental issue of all and the one on which we are and have almost always been furthest apart. You opened On Understanding Science by discussing cumulativeness as the distinguishing feature of science. You then sent me off to look at pre-Newtonian dynamics. I returned from that assignment convinced that science was not cumulative in the most important sense. Newton was not trying to do Aristotle's job better; rather Aristotle had been trying to do a different job and one that Newton did not do so well. Would you say that home industry was merely a less effective way of doing what the factory system later did? ${ }^{16}$

If Newton had been "trying to do Aristotle's job better", Conant's notion of progress could remain standing, Kuhn explained, because the two theoretical projects would be aiming for a common goal; but the Aristotle experience revealed to Kuhn that this was not so. Nodding to the transformations wrought by the industrial revolution, Kuhn asked Conant to see that Newton and Aristotle aimed at goals as different as those of "home industry" and "the factory system". On first reading his manuscript, Conant had objected that Kuhn's picture of scientific revolutions as changes of world view was "far too grandiose". Kuhn's reply, invoking the industrial revolution to categorically distinguish Newton's from Aristotle's physics, probably seemed just as grandiose.

Did Conant recognize that Kuhn's new image of science was inspired by these cold-war preoccupations with liberalism and its confrontation with communism? $\mathrm{He}$ did, but not of course as a historian looking back at the cold-war and its cultural and intellectual effects. Conant read the book as a liberal cold warrior whose careful and selective criticisms reflected the importance he attached to different political dimensions of the historiography of science. He approved, for instance, the restless dynamism of Kuhn's cyclical, never-ending model of revolution. Conant himself had defined science in his On Understanding Science by writing simply that "science moves ahead" (Conant 1947, 25) and never, on pain of dogmatism or authoritarianism, rests content with some theoretical doctrine. Thus he applauded Structure's avoidance of "reality" and "truth"-concepts that he himself had always made a point to reject in the understanding of science.

15 J. B. Conant, letter to T. S. Kuhn, June 5, 1961, p. 3, Box 25, Folder 53 Thomas S. Kuhn Papers, MC240, MIT Library, Institute Archives and Special Collections.

${ }^{16}$ Kuhn to Conant, June 29, 1961. p. 5, Box 25, Folder 53 Thomas S. Kuhn Papers, MC240, MIT Library, Institute Archives and Special Collections. Since Kuhn described the Aristotle experience occuring after Conant had "sent [Kuhn] off to look at pre-Newtonian dynamics" in the late 1940s, it would appear this letter refers indirectly to the experience. Conant discusses his cumulative notion of scientific progress in On Understanding Science (Conant 1947) on pages 20-23. 
But Conant rejected Structure's theory of paradigms. What bothered him most, it seems, was the stipulation that any mature, productive scientific community works under one and only one paradigm. As Conant put it, "You tend to treat the scientific community far too much as a community with a single point of view". Conant's writings on science and liberalism through the 1950s explain why he would have found this uniformity of outlook incorrect, if not offensive. Science was the beating intellectual heart of Conant's liberal anticommunism. He regularly told his audiences that western liberalism was superior to Soviet authoritarianism not as a matter of preference or tradition but as a matter of practical epistemology. Democracy's political freedoms facilitated the intellectual freedoms that alone advance human learning.

In 1955, for example, two years after taking up his first diplomatic post in Germany, Conant returned to Yale to lecture on "The Citadel of Learning". Democracy, he explained, allowed scientists and other progressive intellectuals to "contemplate with pride the labors of those who have worked and argued to advance learning through the centuries". Because such freedoms were not permitted in the Soviet Union or in East Germany, where learning was officially supposed to exalt the official state philosophy of dialectical materialism, Conant's understanding of science and its history merged with his diplomatic defense of democracy and pluralism against communism: "And today", he continued, "with the world divided [between the liberal west and the communist east] scholars and laymen in all the free nations need to reaffirm their resolution to see to it, as far as lies within their power, that the international flag of freedom continues to fly above an inviolate citadel of learning" (Conant 1956, 22).

That was before Kuhn had anything more than notes and outlines for Structure. Years later, shortly after Structure was published, Conant warmed up to the book, even praising it as "brilliant" (Conant 1964, 13) in a book titled Two Modes of Thought. Yet even while promoting the book and its author, Conant's praise was specific and selective. While other reviews of Kuhn's book zeroed in on its provocative theory of paradigms, Conant did not even mention the word "paradigm". In light of his longstanding critique of Soviet culture for turning its back on liberalism and officially embracing a single all-embracing ideological program, we can only wonder how Conant would have reacted to Structure had he seen earlier drafts and outlines written before Kuhn formulated his new theory of paradigms. In the mid and late 1950s, Kuhn had a different conception of the shared conceptual structure that unified and guided a scientific community and made professional science possible. These structures were not the same as paradigms, but any functioning scientific community shared one and only one. Kuhn called it "an ideology". 


\section{REFERENCES}

Cedarbaum, Daniel Goldman 1983. Paradigm. Studies in History and Philosophy of Science 14: 173-213.

Chambers, Whittaker. 1952. Witness. Washington, D.C.: Regnery.

Committee on Un-American Activities 1958. Communist Psychological Warfare (Brainwashing): Consultation with Edward Hunter. Washington, D.C.: U.S. Government Printing Office, March 13.

Conant, James B. 1947. On Understanding Science. New Haven: Yale.

- 1956. The Citadel of Learning. New Haven: Yale.

—. 1964. Two Modes of Thought. New York: Trident.

—. 1970. My Several Lives: Memoirs of a Social Inventor. New York: Harper \& Row.

Crombie, A.C., ed. 1961. Scientific Change. New York: Basic Books.

Fleck, Ludwig 1979. Genesis and Development of a Scientific Fact, ed. Thaddeus Trenn and Robert Merton, Chicago: University of Chicago Press.

Fuller, Steve. 2000. Thomas Kubn: A Philosophical History for Our Times. Chicago: University of Chicago Press.

Gleason, Abbot 1995. Totalitarianism: The Inner History of the Cold War. Oxford: Oxford University Press.

Hershberg, James 1993. James B. Conant: Harvard to Hiroshima and the Making of the Nuclear Age. New York: Knopf.

Hofstadter, Richard, 1963. Anti-Intellectualism in American Life. New York: Knopf.

- 1964. The Paranoid Style in American Politics. In The Paranoid Style in American Politics, ed. Sean Wilentz, New York: Random House, pp. 3-40 (orig: Harper's Magazine, November 1964, pp. 77-86).

Hoover, J. Edgar 1958. Masters of Deceit. New York: Henry Holt.

Hunter, Edward 1953 [orig: 1951]. Brainwashing in Red China: The Calculated Destruction of Men's Minds. New York: Vanguard Press.

Isaac, Joel 2012. Kuhn's Education: Wittgenstein, Pedagogy, and the Road to Structure. Modern Intellectual History 9: 89-107.

Jacobs, Struan, 2006/2007. Michael Polanyi and Thomas Kuhn: Priority and Credit. Tradition and Discovery: The Polanyi Society Periodical, v. 33, no. 2, 25-36.

—. 2009. Thomas Kuhn's Memory. Intellectual History Review 19: 83-101.

Koestler, Arthur 1941. Darkness at Noon. New York: Macmillan.

- . 1950. Arthur Koestler. In The God that Failed, R. Crossman, ed., London: Hamilton, (reprinted by Columbia University Press, 15-75)

—. 1959. The Sleepwalkers: A bistory of Man's Changing Vision of the Universe. New York: Arkana.

Kuhn, Thomas 1959. The Essential Tension: Tradition and Innovation in Scientific Research. In Kuhn 1977, 225-239.

- 1961. The Function of Dogma in Scientific Research. In A.C. Crombie, ed., Scientific Change, New York: Basic Books, 347-369.

- 1962. The Structure of Scientific Revolutions, 3rd edition (1996). Chicago: University of Chicago Press.

-. 1964. A Function for Thought Experiments [orig: in L'aventure de la science, Mélanges Alexandre Koyré, Paris: Hermann, 2: 307-334]. In Kuhn 1977, 240-265.

—. 1971. Concepts of Cause in the Development of Physics [orig: Etudes d'épistémologie génétique 25, 7-18]. In Kuhn 1977, 21-30.

-. 1977. The Essential Tension, Chicago: University of Chicago Press.

—. 1979. Forward to Fleck 1979, vii-xi

- 2000. The Road Since Structure, ed. James Conant and John Haugeland, Chicago: University of Chicago Press.

Lakatos, Imre and Alan Musgrave, eds. 1970. Criticism and the Growth of Knowledge. Cambridge: Cambridge University Press.

Mayoral, Juan V. 2009. Intensions, Belief, and Science: Kuhn's Early Philosophical Outlook (1940-1945). Studies in History and Philosophy of Science 40: 175-184.

McCumber, John. 2001. Time in the Ditch: American Philosophy and the McCartby Era. Evanston: Northwestern University Press. 
Melley, Timothy 2008. Brainwashed! Conspiracy Theory and Ideology in the Postwar United States. New German Critique 103, vol. 35: 145-64.

Packard, Vance. 1957. Hidden Persuaders. New York: David McKay.

Peale, Norman Vincent. 1952. The Power of Positive Thinking, New York: Prentice-Hall.

Polanyi, Michael. 1958. Personal Knowledge: Towards a Post-Critical Philosophy, Chicago: University of Chicago Press.

Reisch, George A. Forthcoming. When Structure Met Sputnik: On the Cold-War Origins of The Structure of Scientific Revolutions. In Nations and Knowledges, edited by John Krige and Naomi Oreskes.

-. 2005. How the Cold War Transformed Philosophy of Science: To the Icy Slopes of Logic. Cambridge: Cambridge University Press.

Rudolph, John. 2002. Scientists in the Classroom. Palgrave McMillan.

Schrecker, Ellen W. 1986. No Ivory Tower: McCarthyism and the Universities. New York: Oxford University Press.

Sinatra, F. et al.1962. The Manchurian Candidate. Film. Directed by J. Frankenheimer. Los Angeles: United Artists.

George Reisch is an editor at Open Court Publishing Company and teaches in Northwestern University's School of Continuing Studies. He is the author of How the Cold War Transformed Philosophy of science and is currently writing a book on the cold-war origins of Kuhn's Structure.

AdDREss: George Reisch, Open Court Publishing Company. 70 East Lake Street, Chicago, IL 60601. Email: greisch@caruspub.com 